\title{
Research Paper \\ The Effect of Social Skills Training on Subjective Well-being, Alexithymia, and Social Competence in Children with Oppositional Defiant Disorder
}

\author{
Narges Khatoon Zabihi Hesari ${ }^{1}$, Zeinab Hoveizeh ${ }^{2}$, Seyyedeh Elham Mokhtari Yousefabad ${ }^{3}$, Tayyebeh Hoseini ${ }^{4}$, \\ Samineh Bahadori Jahromi*5 \\ 1. Assistant Professor, Department of Psychology, Faculty of Literature and Humanity Sciences, Payame Noor University, Tehran, \\ Iran \\ 2. M.A. of Clinical Psychology, Ahvaz Branch, Islamic Azad University, Ahvaz, Iran \\ 3. M.A. of Rehabilitation Consulting, Jahad University Researcher, Kohgiluyeh and BoyerAhmad, Iran \\ 4. M.A. of Educational Psychology, Faculty of Literature and Humanity Sciences, Semnan University, Iran \\ 5. Assistant Professor, Department of Sociology, Bandar Abbas Branch, Islamic Azad University, Bandar Abbas, Iran
}

Citation: Zabihi Hesari NK, Hoveizeh Z, Mokhtari Yousefabad SE, Hoseini T, Bahadori Jahromi S. The effect of social skills training on subjective well-being, alexithymia, and social competence in children with oppositional defiant disorder. Quarterly Journal of Child Mental Health. 2019; 6(3): 138-148.

http://dx.doi.org/10.29252/jemh.6.3.13

\section{A R T I C L E I N F O}

Keywords:
Oppositional defiant
disorder,
social skills training,
subjective well-being,
alexithymia,
social competence

Received: 21 Apr 2018 Accepted: 10 Aug 2018 Available: 9 Nov 2019

\section{A B S T R A C T}

Background and Purpose: Oppositional defiant disorder is one of the most common disruptive behavioral disorders and people with this disorder are facing with problems in the field of mental well-being, alexithymia, and social competence. The aim of this research was to investigate the effect of social skills training on subjective well-being, alexithymia, and social competence of children with oppositional defiant disorder.

Method: This research was a semi-experimental study with a pre-test and post-test control group design. The research sample consisted of 40 children with oppositional defiant disorder who had been selected by convenience sampling from among those referring to the counseling centers of Qarchak city in 2017 . They were assigned either to the experimental or the control group (20 children per group). The experimental group received social skills intervention in 8 sessions of 60 minutes during one month. Research tools included oppositional defiant disorder scale (Hommersen et al., 2006), subjective well-being questionnaire (Keyes \& Magyar-Moe, 2003), Toronto alexithymia scale (Bagby \& et al, 1994), and social competence questionnaire (Flener \& et al, 1990). Data were analyzed by univariate analysis of covariance.

Results: The results showed that there was a significant difference between the experimental and control groups in all the three variables of subjective well-being, alexithymia, and social competence. In the other words, social skills training significantly led to the increase of subjective well-being and social competence and decrease of alexithymia in children with oppositional defiant disorder $(\mathrm{P}<0.01)$.

Conclusion: Considering the findings, it can be concluded that by improving the social relationships and problem solving, the social skills training can improve the psychological and social competence and decrease the alexithymia symptoms in children with oppositional defiant disorder.

\footnotetext{
* Corresponding author: Samineh Bahadori Jahromi, Assistant Professor, Department of Sociology, Bandar Abbas Branch, Islamic Azad University, Bandar Abbas, Iran.

E-mail addresses: Bahadori.jahromi@yahoo.com
} 


\section{تأثير آموزش مهارت هاى اجتماعى بر بهزيستى ذهنى، ناكويى هيجانى، و كفايت اجتماعى كود كان با اختلال نافر مانى مقابلهاى}

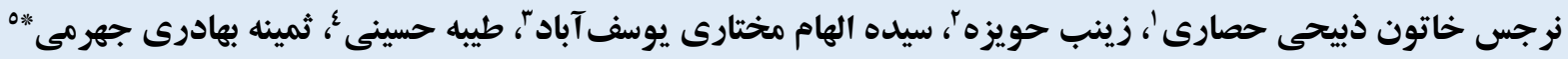

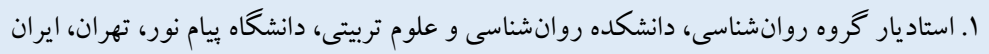

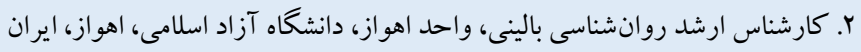

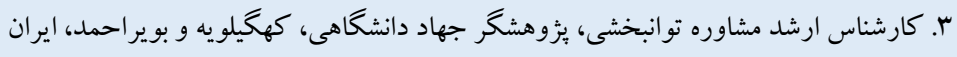

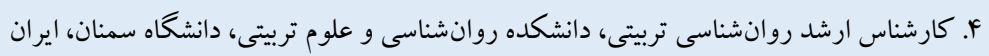

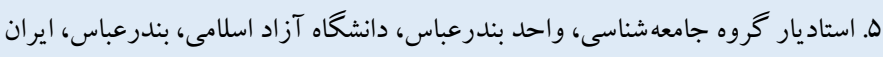

\section{جكيده}

زمينه و هدف: يكى از شـايع ترين اختلال هاى رفتار مخرب، اختلال نافرمانى مقابلهاى اسـت و اين افراد با مشكلاتى در زمينه سلامت روانى،

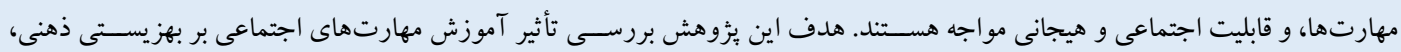

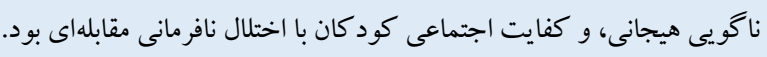

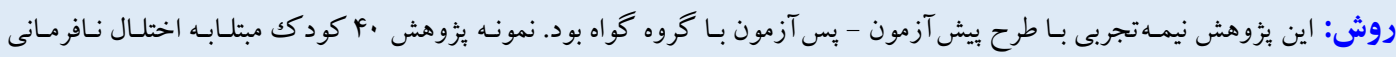

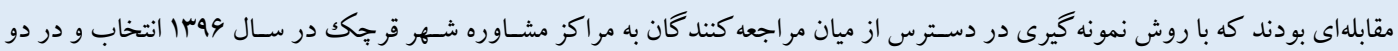

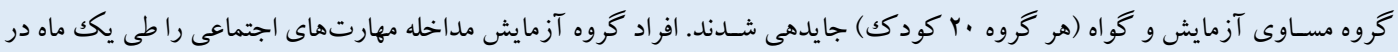

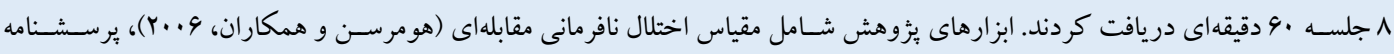

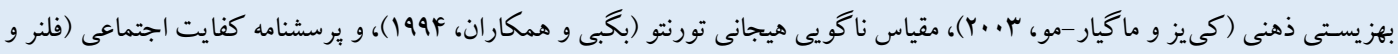

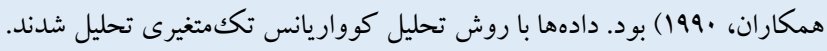

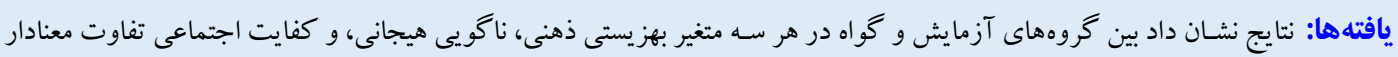

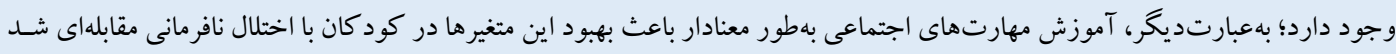

$(\mathrm{P}<\cdot / \cdot 1)$

نتيجــه كيرى: بـا توجـه بـه يـافتههاى بهدسـت آمده در اين مطالعه مى توان نتيجه كرفت كه آموزش مهارتهاى اجتماعى با بهبود روابط

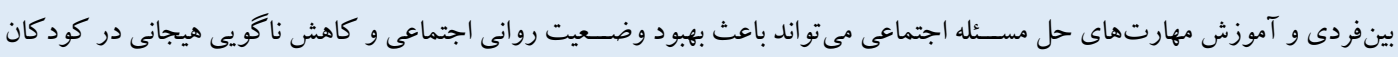
مبتلابه اختلال نافرمانى مقابلهاى شود.
مشخصات مقاله

كليدوازهها:

اختلال نافرمانى مقابلهاى،

مهارتهاى اجتماعى، بهزيستى ذهنى،

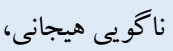

كفايت اجتماعى

* نويسنده مسئول: ثمينه بهادرى جهرمى، استاديار گروه جامعهشناسى، واحد بندرعباس، دانشگاه آزاد اسلامى، بندرعباس، ايران.

Bahadori.jahromi@yahoo.com : رايانامه تلفن تماس: . . V4 - V4900 - 
مقدمه

نـاكويى هيجانى تهييج هاى بدنى نابهنجار را بزرك مى كنند، نشـانهاى

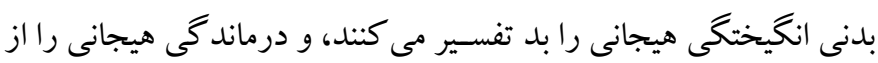

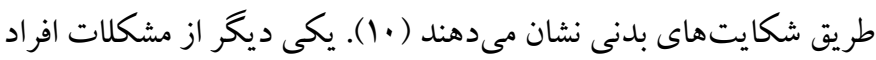

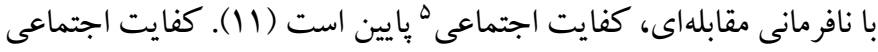

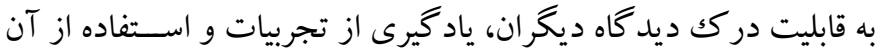

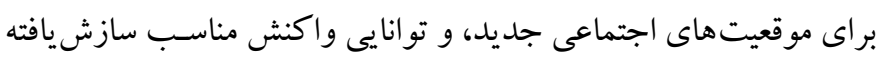

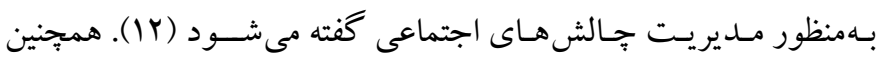

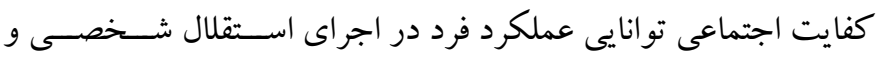
مسـئوليت يذيرى اجتماعى اسـت كه شامل مهارت هاى شناختى، رفتارى،

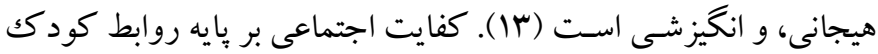

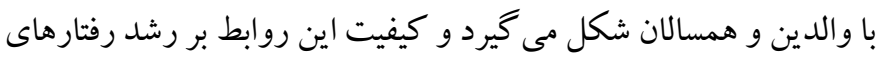

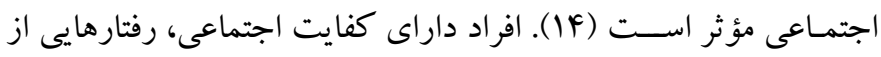
خود نشـــان مى دهنــد كه منجر به بيامدهاى مثبت روانى - اجتماعى مانند

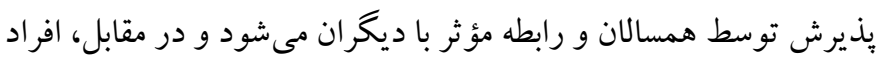
فاقد كفايت اجتماعى اغلب دجار مشـكلات رفتارى در تعامل با ديخران

بهويزه همسالان هستند (1ه).

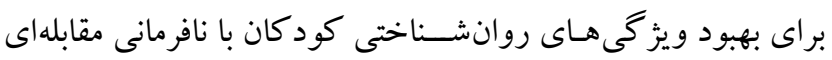

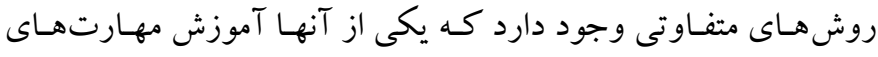

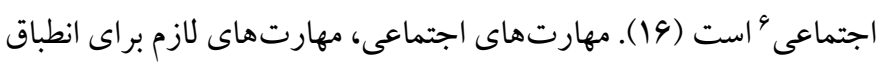
با نيازهاى اجتماعى و حفظ روابط بين فردى رضايتبخش هستند (IV).

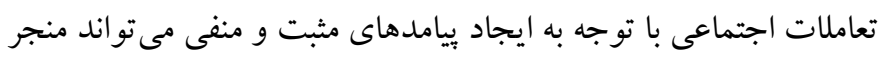

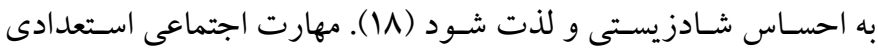
است كه باعث انجام رفتارهاى منجر به تقويت مى شود، نه رفتارهايى كه

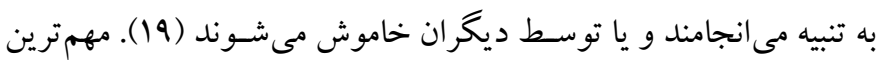

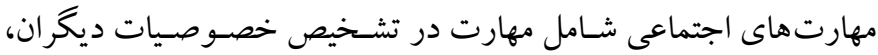

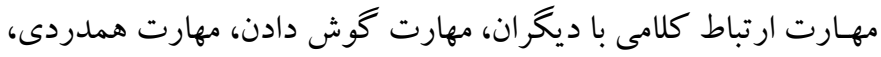

$$
\text { و مهارت ارتباط غير كلامى هستند (r). }
$$

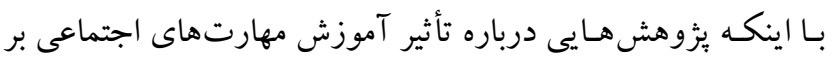
بهزيسـتى ذهنى، نـاكويى هيجـانى، و كفايت اجتماعى انجام شــــه، اما

\section{Alexithymia}

5. Social competence

6. Social skills training
اختلال نافرمانى مقابلهاى' در ويراست ينجم راهنماى تشخيصى و آمارى

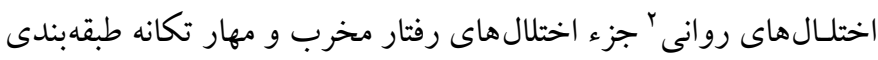

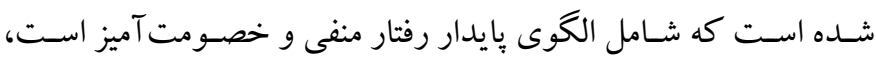

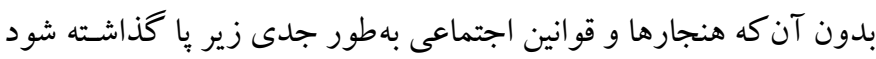

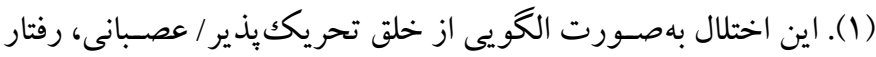

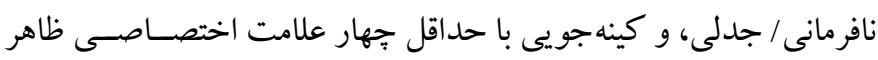

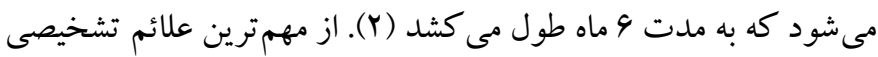

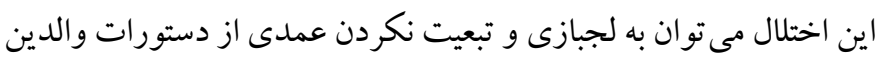

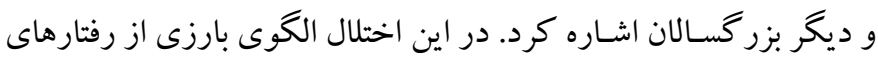

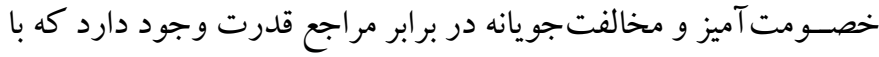

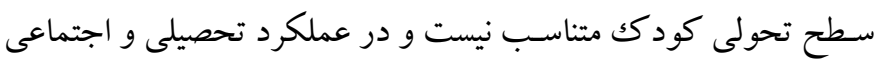

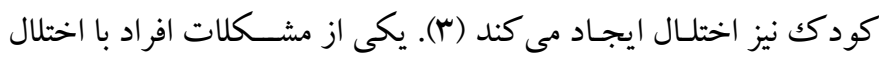

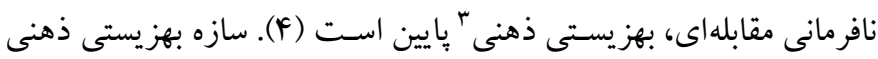

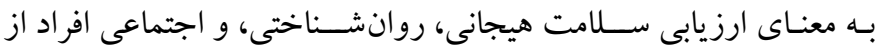

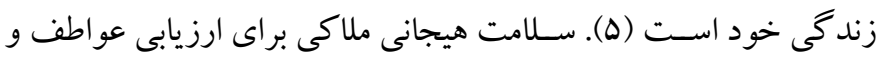

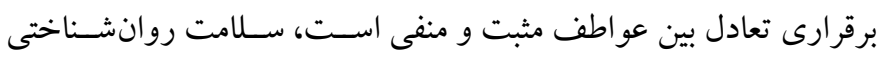

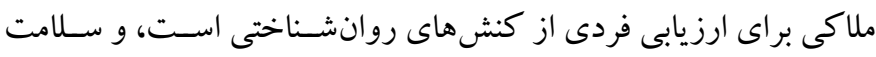

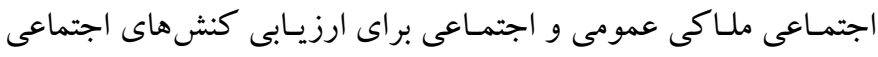

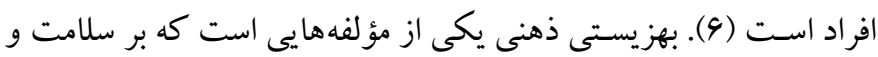

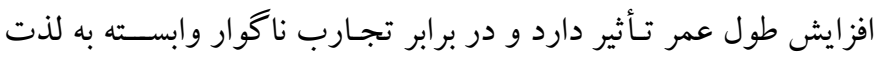

يكى ديخر از مشـكلات افراد با اختلال نافرمانى مقابلهاى، مشـكلات

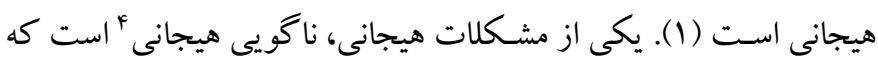
نوعى نارسايى خلقى است كه باعث ناتوانى در بردازش شناختى اطلاعات

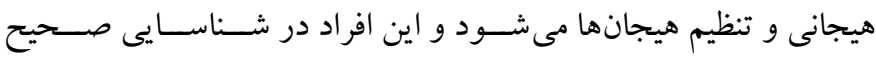

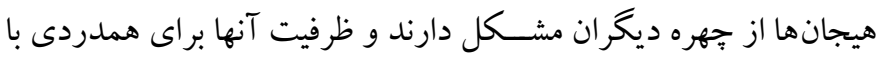

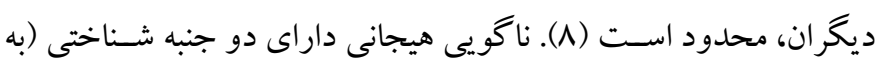
معناى ناتوانى در شـناسـيى، فهم و تفسير احساسات) و عاطفى (به معناى

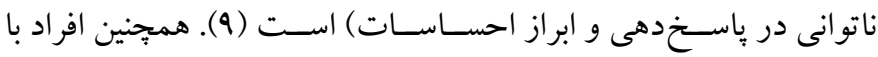

1. Oppositional defiant disorder (ODD)

2. Diagnostic and statistical manual of mental disorders-5

3. Subjective well-being 
حاضـر به دنبال باسـخ گويى به آن اسـت. در نتيجه، اين يُزوهش با هدف

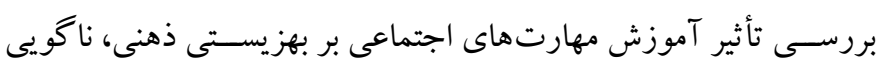

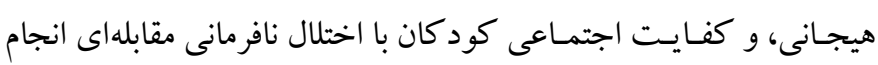

شد.

\section{روش}

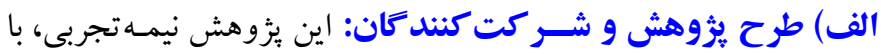

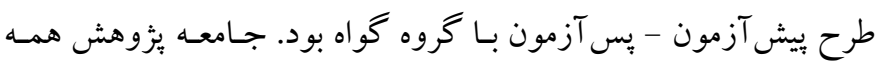

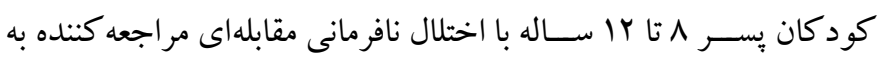

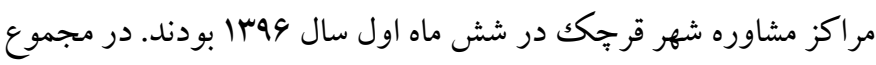

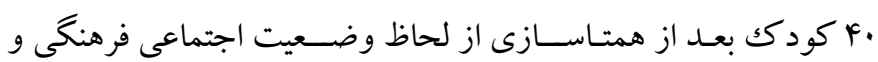
نداشتن اختلالهاى همزمان ديخر با روش نمونه گيرى در دسترس انتخاب

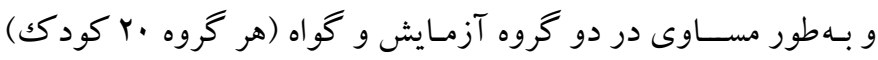

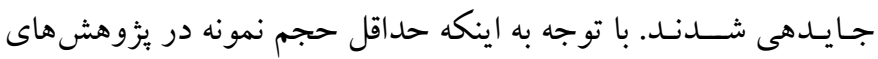

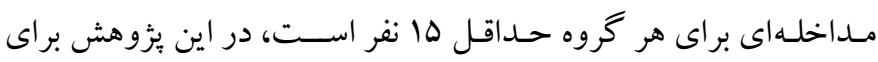

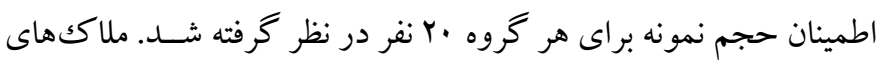

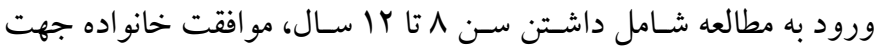

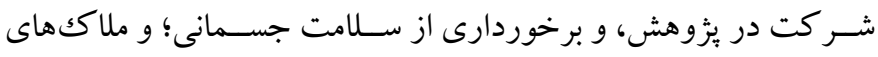

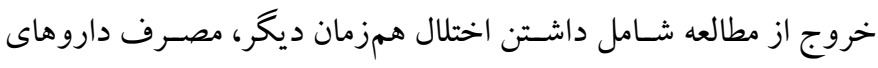

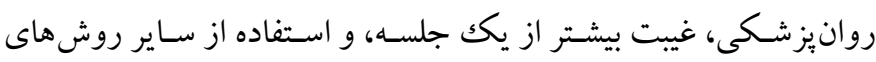

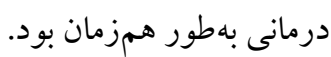

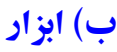

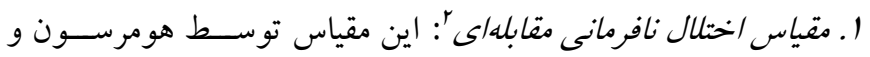

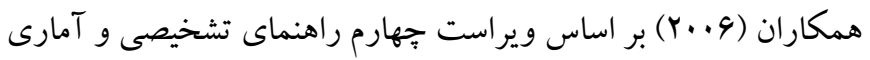
اختلالات روانى براى تشــخيص كودكـان بـا اختلال نافرمانى مقابلهاى

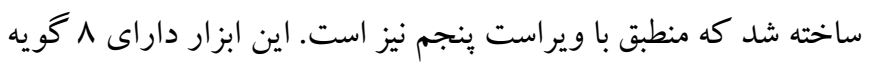

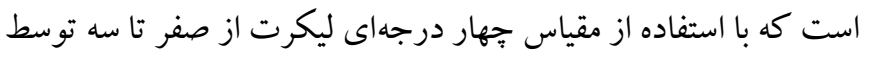

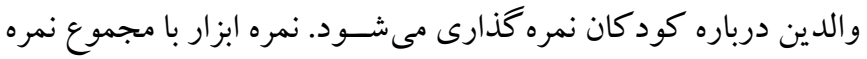

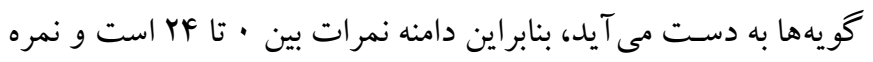

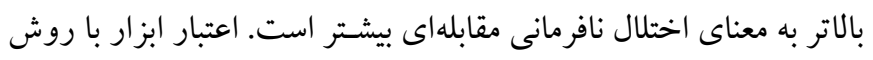

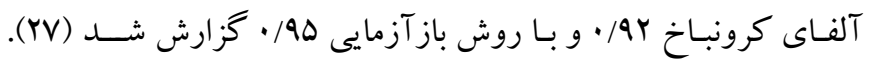

يزؤهشـى در اين زمينه بر روى كود كان مبتلابه اختلال نافرمانى مقابلهاى

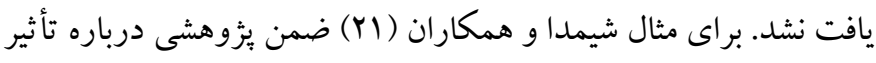

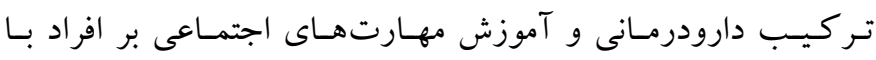

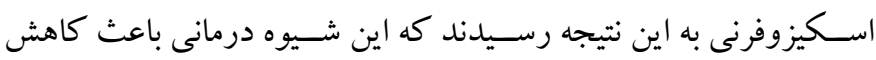

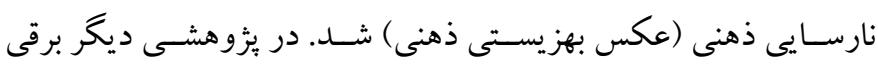

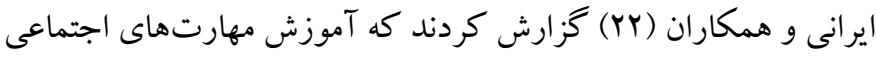
مبتنى بر يردازش شناختى، بر افزايش بهزيستى ذهنى (بهزيستى اجتماعى،

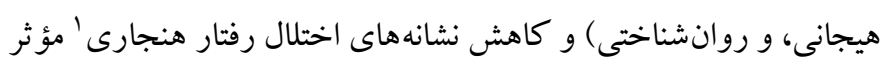

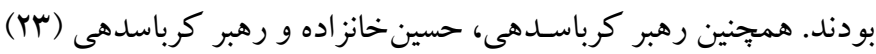

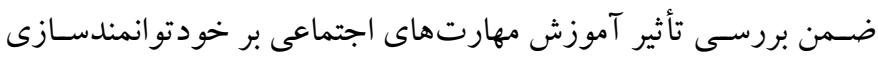

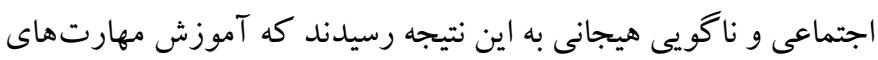

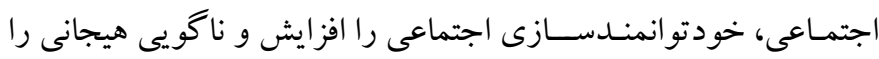

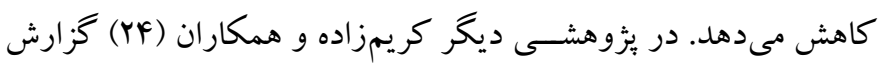

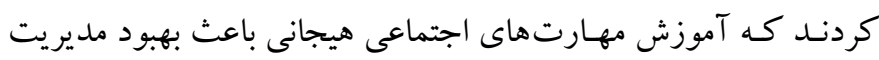
تنيـدگى و خلق كلى فرد مى شـــود. علاوه بر آن مؤمنى و همكاران (YD)

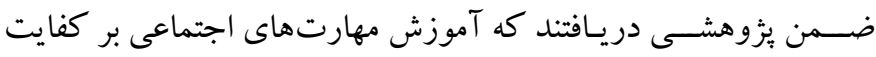
اجتماعى و هيجانى دانش آموزان با اختلال رياضسى مؤثر اسـت. و بالاخره

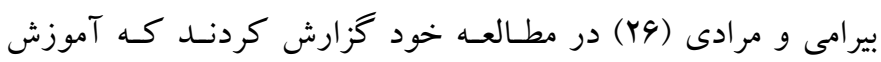
مهارتهاى اجتماعى بر ارتقاء كفايت اجتماعى دانش آموزان مؤثر بود.

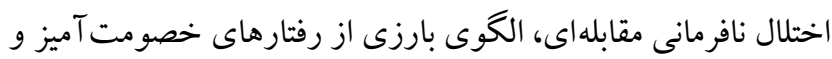

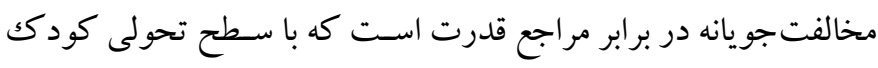
متناسـب نيسـت و در عملكرد تحصـيلى و اجتماعى كود كك نيز اختلال

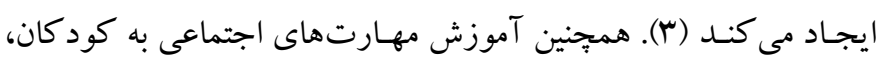

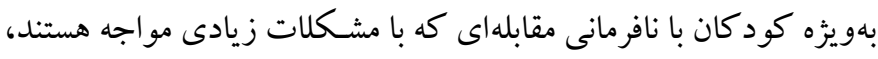

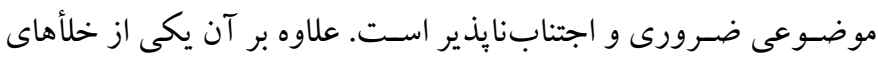

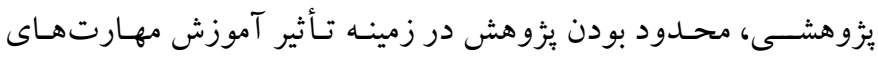

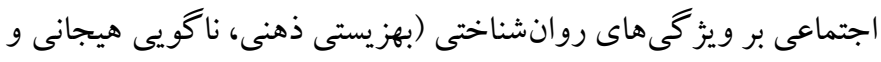

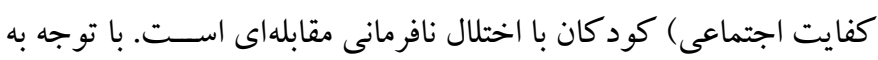

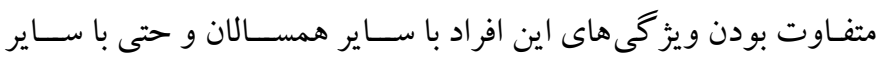

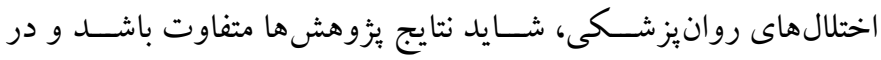

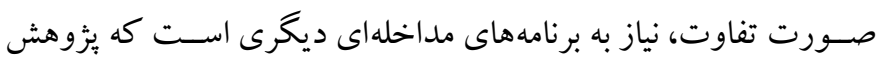

1. Conduct disorder 
درماندگى روانشـناختى عF/×، و اعتبار آن رابا روش آلفاى كرونباخ

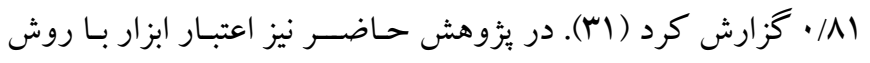
آلفاى كرونباخ AV/ آ • محاسبه شد.

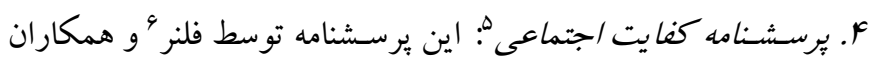

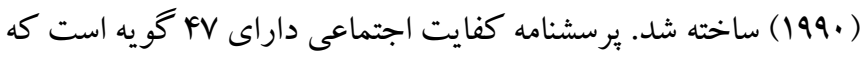
با استفاده از مقياس هفت درجهاى ليكرت از يكك تا هفت توسط والدئ ئرسئ

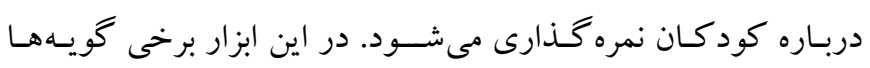

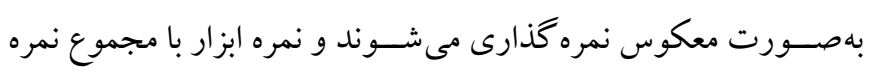

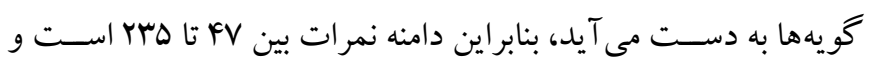

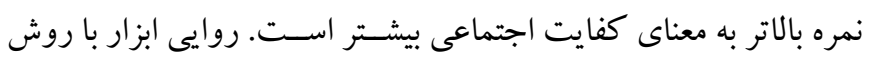

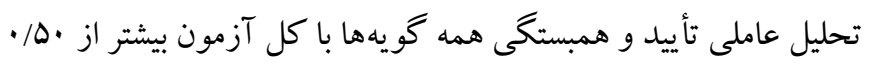

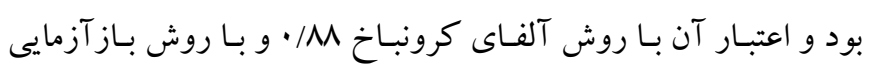

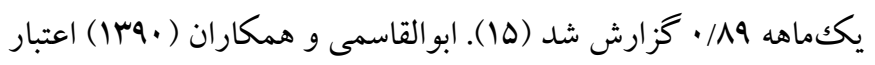

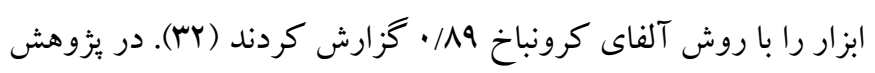

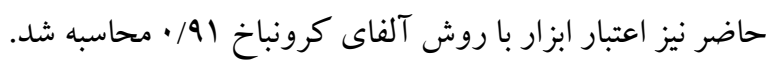

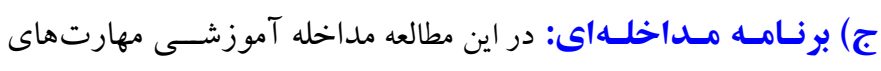

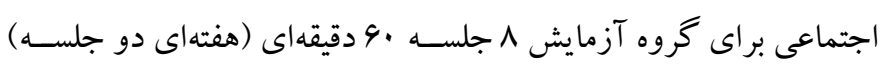

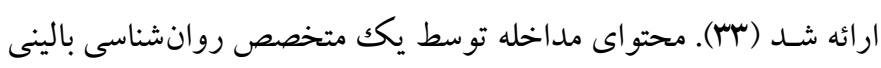

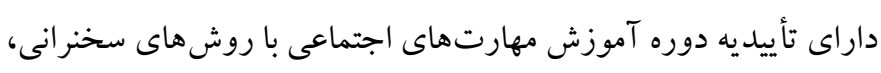

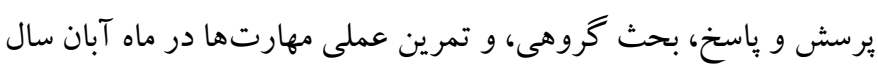

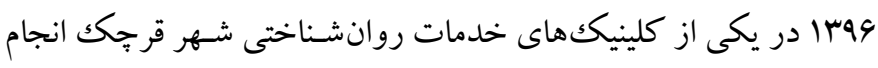

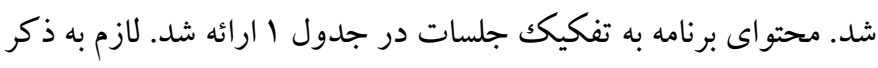

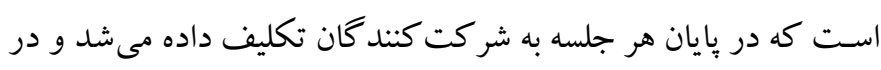

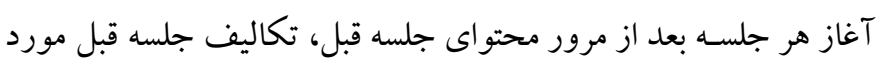

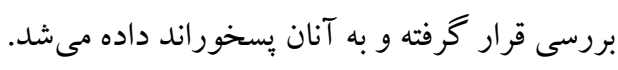

4. Bagby

5. Social competence questionnaire 6. Flener
همجِنين بهروزى و همكـاران (هوبا) روايى محتوايى ابزار را بـا نظر

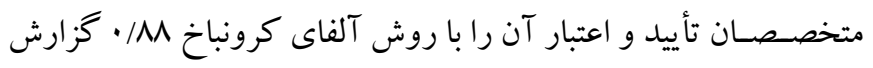

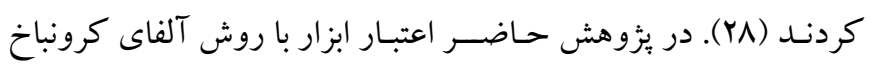
م/ • • محاسبه شد.

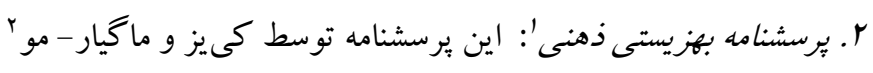

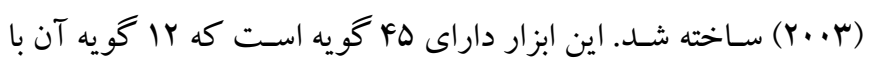

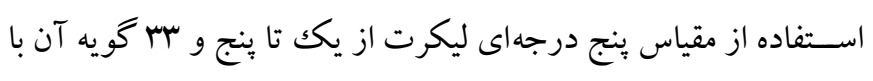

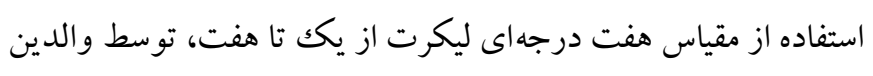

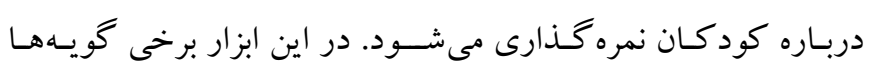

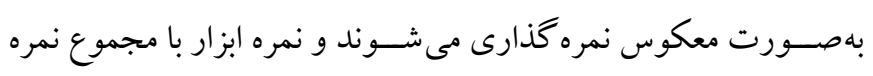

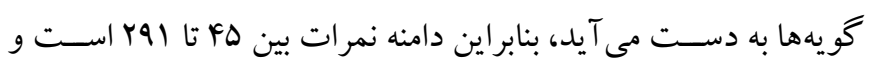

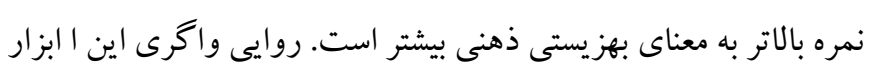

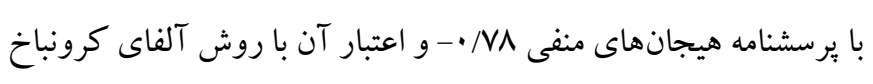

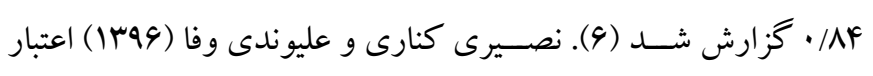

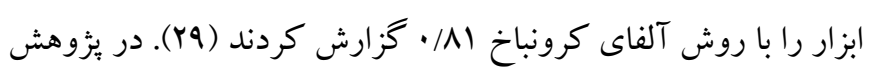

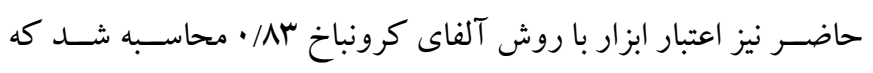
مطلوب است. r. مقياس ناكويى هيجانى توزنتوّ": اين مقياس توسط بخبى بو همكاران

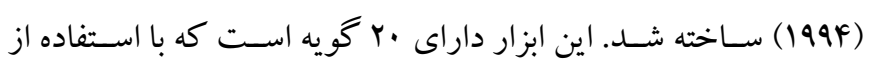

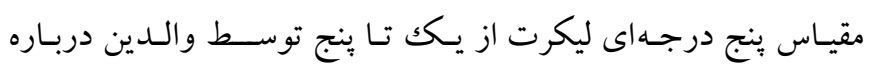

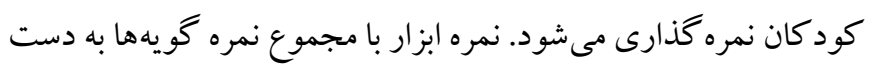

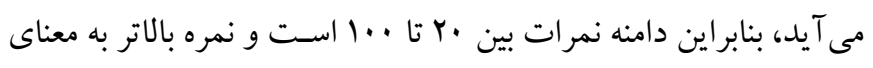
ناكويى هيجانى بيشتر است. روايى محتوايى ابزار با نظر متخصصان تأييد

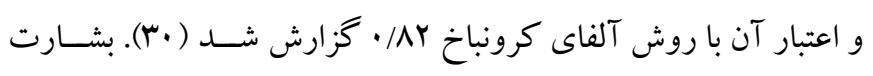

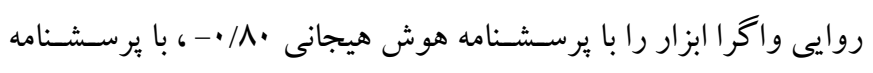

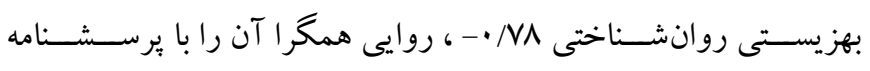

1. Subjective well-being questionnaire

2. Keyes \& Magyar-Moe

3. Toronto alexithymia scale 


\begin{tabular}{|c|c|}
\hline محتوا & جلسات \\
\hline آشنايى، بيان قوانين و ضوابط دوره آموزشى و محتواى هشت جلسه بهصورت مختصر، تشريح اهداف دوره در خارجوب بهزيستى، ناگويى هيجانى، كفايت اجتماعى، آموزش روشهاى & يكم \\
\hline آموزش مهارت هاى گوش دادن، تفاوت گوش دادن و شنيدن، توجه و ييخيرى و تمرين روابط بين فردى، نحوه ارتباطات و صحبت كردن مؤثر & دوم \\
\hline 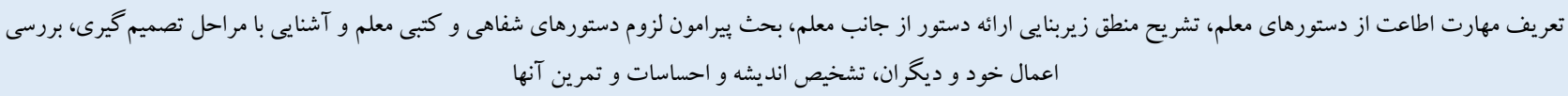 & سوم \\
\hline تشريح و تمرين مهارت هاى ارتباط كلامى و غير كلامى، گوش دادن و ياسخ دادن، ادامه دادن مكالمه، شناخت احساسات، رعايت نوبت، و مسئوليت يذيرى بيامدهاى تصميم شخصى & جهارم \\
\hline آموزش مهارتهاى همر اهى با ديخران، احترام كذاشتن به تفاوت هاى فردى، درك احساسات و علايق ديخران و سازش با ديخران از طريق مفهوم سازش و كاركردهاى آن & ينجم \\
\hline 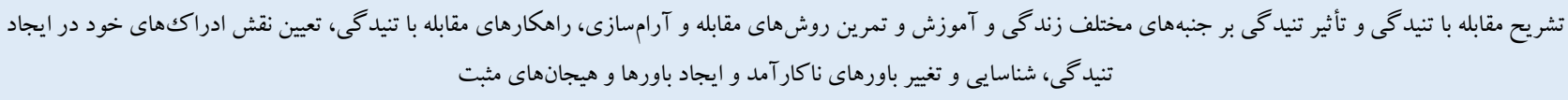 & ششم \\
\hline آموزش و تشريح انعطاف يذيرى در برابر تغييرهاى احتمالى، لزوم انعطافيذيرى در رسيدن به اهداف و سازش يافتن، نحوه انعطاف يذيرى، و نقش آن در زندگى & هفتم \\
\hline تعريف مهارتهاى مقابلهاى و بيان كار كردها و منطق زيربنايى آن، آموزش نحوه جلو گيرى از بايمال شدن حقوق خود، بيان آزادانه مواضع خود در روابط بين فردى، و برنامهريزى & هشتم \\
\hline
\end{tabular}

\section{يافتهها}

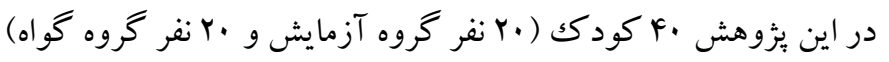

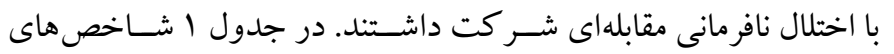

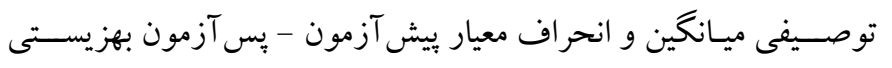

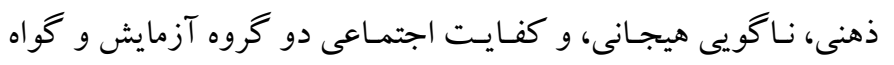

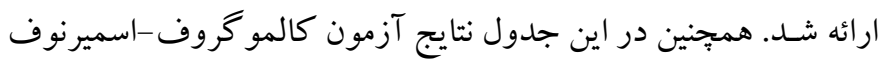

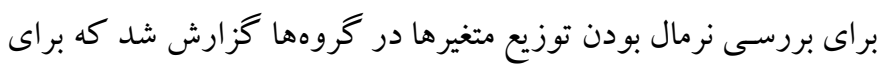

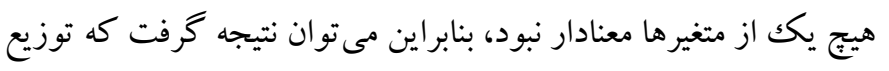

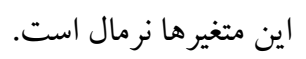

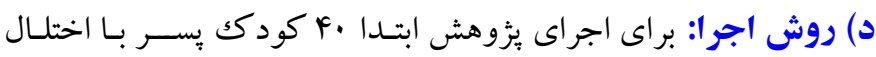

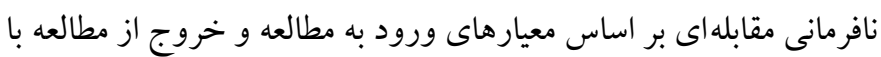
روش نمونه گيرى در دسترس انتخاب و بهصورت تصادفى در دو گرووه

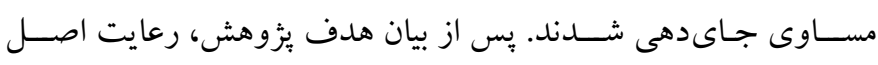

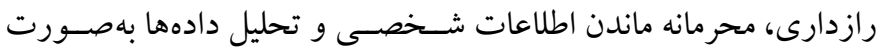

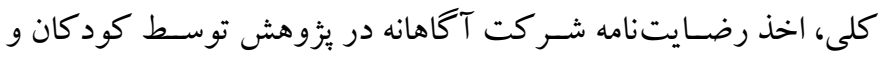
يكى از والدين آنها، ابزارهاى برزوهش توسط يكى إنى از والدين تكميل شد.

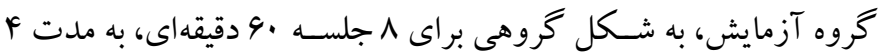

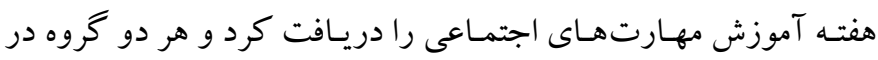

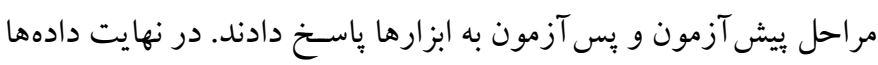

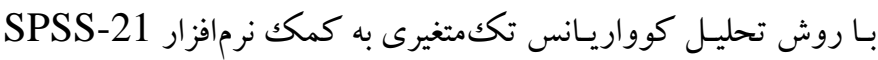
تحليل شدند.

جدول r: شاخصهاى توصيفى نمرات يِش آزمون - يس آزمون متغيرهاى يزوهش در دو كروه آزمايش و كواه (تعداد: •ع نفر )

\begin{tabular}{|c|c|c|c|c|c|c|}
\hline $\mathbf{P}$ & K-S & انحراف معيار & ميانكين & كروه & وضعيت & متغيرها \\
\hline.$/ \mathrm{Vr}$ &.$/ 194$ & $|N|$. & $\Lambda r / r F$ & آزمايش & \multirow{2}{*}{ ييش آزمون } & \multirow{4}{*}{ بهزيستى ذهنى } \\
\hline$\cdot / r .$. & $\cdot / 111$ & $I V / 9 Y$ & $\Lambda \Delta / \vee \varphi$ & كواه & & \\
\hline $.1 .9 \mathrm{~V}$ & $\cdot / 1 \wedge 1$ & $r r / 9 \Lambda$ & $1.9 / 21$ & آزمايش & \multirow{2}{*}{ ֶֶ آزمون } & \\
\hline$\cdot / r \cdot$. &.$/ 11 r$ & IN/IT & $\Lambda F / \lambda Q$ & كواه & & \\
\hline$\cdot / r \cdot$. & $\cdot / 1 \cdot 1$ & V/Ir & $r \Delta / 19$ & آزمايش & \multirow{2}{*}{ بيش آزمون } & \multirow{5}{*}{ ناگويى هيجانى } \\
\hline$\cdot / r \cdot$ & $\cdot / 11 r$ & $V / r q$ & $M / M$ & كو اه & & \\
\hline$\cdot / r \cdot$. & $\cdot / \cdot v q$ & $\Delta / \wedge \Delta$ & $\mathrm{TV} / \cdot \mathrm{F}$ & آزمايش & \multirow{2}{*}{ پֶ آزمون } & \\
\hline$\cdot / r \cdot$. & . & $V / r^{4}$ & $\mu F / \Delta V$ & كواه & & \\
\hline$\cdot / \cdot \wedge r$ & $\cdot / 1 V r$ & $19 / \Delta \Delta$ & AV/VG & آزمايش & ييش آزمون & \\
\hline
\end{tabular}




\begin{tabular}{|c|c|c|c|c|c|c|}
\hline$\cdot / r \ldots$ & אזות & IV/T. & $\Lambda \Delta / Q F$ & كواه & & كفايت اجتماعى \\
\hline.$/ 19 F$ &.$/ 19$ & $r T / V G$ & $|r \Delta / 9|$ & آزمايش & : & \\
\hline$\cdot / 4 \ldots$ &.$/ 119$ & 19/NT & $N V / F Y$ & كو اه & & \\
\hline
\end{tabular}

اجتماعى (T)

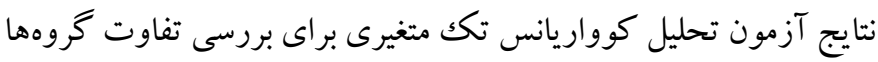
در متغيرهـاى بهزيسـتى ذهنى، ناگويى هيجانى و كفايت اجتماعى ارائه شد.
براى بررسـى تأثير آموزش مهارت اجتمـاعى بر بهزيســى ذهنى،

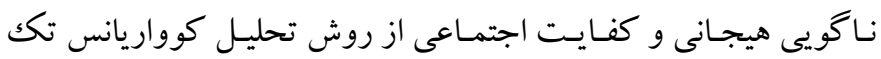

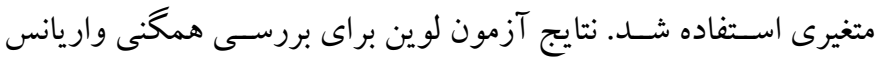

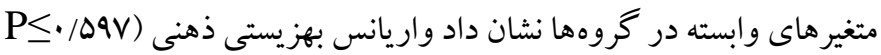

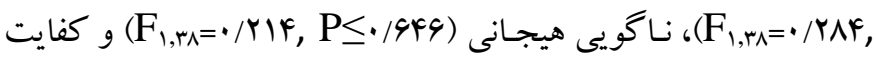

جدول ": نتايج تحليل كوواريانس تكمتغيرى براى بررسى تأثير آموزش مهارتهاى اجتماعى بر بهزيستى ذهنى، ناكويى هيجانى، و كفايت اجتماعى كودكان با اختلال

\begin{tabular}{|c|c|c|c|c|c|c|c|}
\hline \multicolumn{8}{|c|}{ نافر مانى مقابلهاى } \\
\hline اندازه اثر & $\mathbf{P}$ & Tاره F & ميانكين مجذورات & درجه آزادى & مجموع مجذورات & منبع & متغيرها \\
\hline \multirow[t]{2}{*}{$\cdot / \mathrm{VI}$} &.$/ .1$ & $F F / N \Delta$ & $99 \pi / r 1$ & 1 & $994 / Y 1$ & كروه & بهزيستى ذهنى \\
\hline & & & $10 / 9 \pi$ & rv & $\Delta V A / T I$ & خطا & \\
\hline \multirow[t]{2}{*}{$\cdot / \Delta r$} &.$/ .1$ & $r r / a r$ & $\mid k q / F V$ & 1 & $\mid q \varepsilon / F V$ & خروه & ناخو يى هيجانى \\
\hline & & & $9 / 1 r$ & rv & rYG/FF & خطا & \\
\hline \multirow[t]{2}{*}{$\cdot / \mathrm{vA}$} &.. .1 & $r 9 / 99$ & $9 / \Delta / \Lambda$. & 1 & $9 / \Delta / \wedge$. & خروه & كفايت اجتماعى \\
\hline & & & $r F / 99$ & rv & Qrr/Dr & خطا & \\
\hline
\end{tabular}

تر كيب دارودرمانى و آموزش مهارتهاى اجتماعى بر كاهش نارسـايى

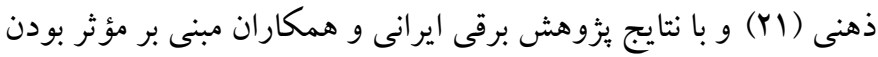

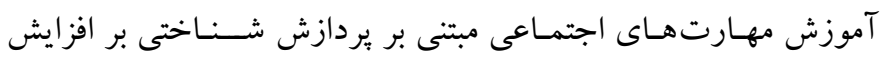
بهزيسـتى ذهنى (Yr) همسـو اسـت. اين يافته را بر مبناى نظر كو كك و

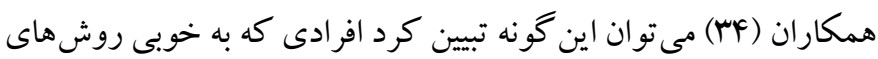
انجام رفتارهاى مطلوب و كسب تقويت را ياد نكر فتند، يكى از مشكلات اصلى آنان ناتوانى در ارزيابى و نظارت بر رفتارشان است كه اين موضوع

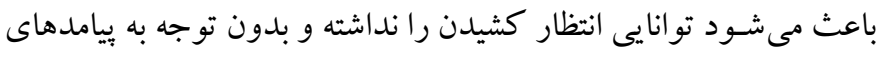

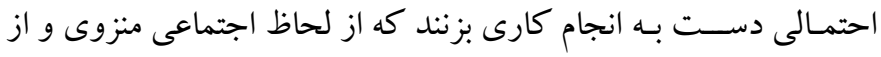

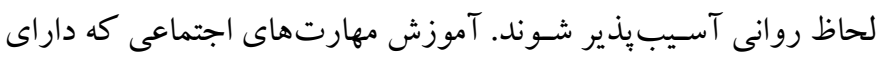

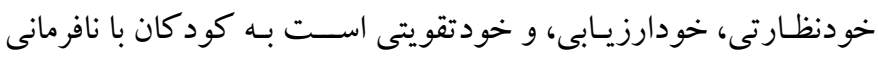

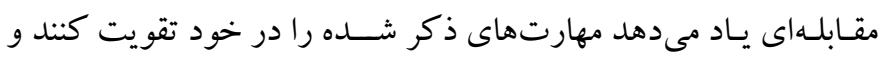

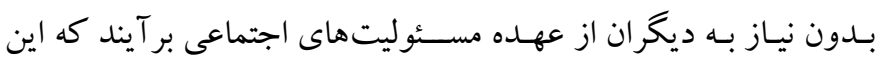

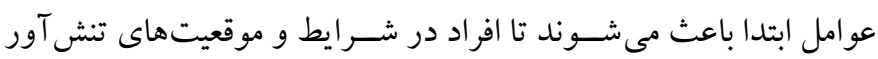

بر اسـاس نتايج جدول سا، بين دو گروه در هر سـهـ متغير بهزيسـتى

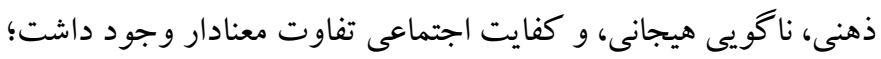

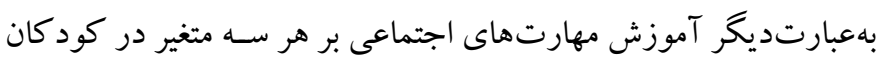

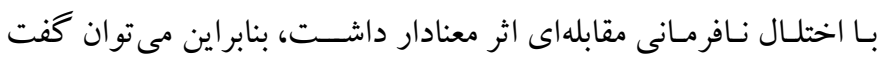

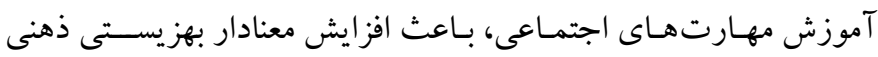

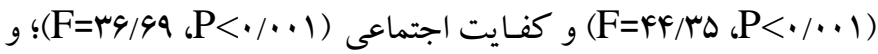

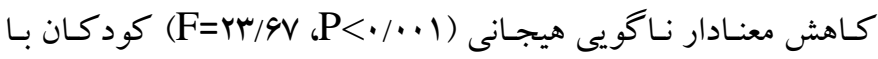
اختلال نافرمانى مقابلهاى شد.

\section{بحث و نتيجه كيرى}

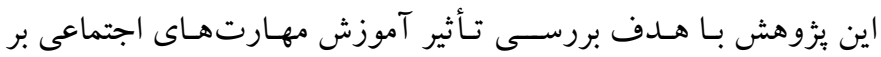
بهزيسـتى ذهنى، ناكويى هيجانى، و كفايت اجتماعى كود كان با اختلال

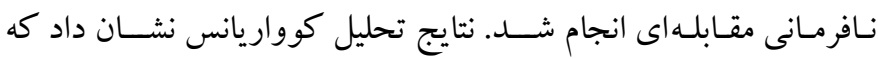

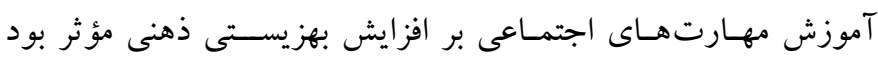

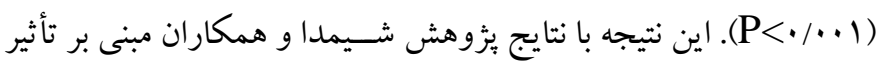


افر اد ياد مى گيرند جگگونه تصميم گيرى كنند، افكار منفى خود را با افكار

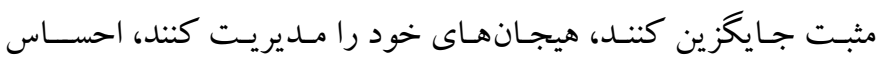

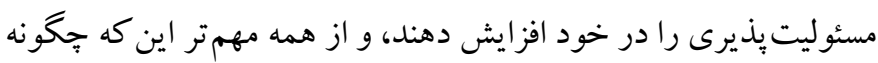

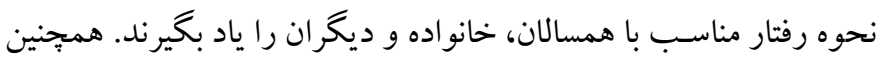
افراد در فرايند آموزش مهارتهاى اجتماعى مطلع مىشـوند كه بين آنها

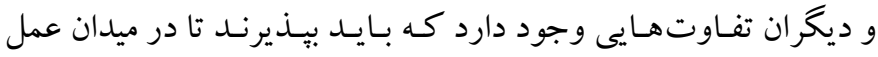

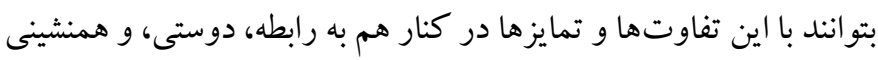

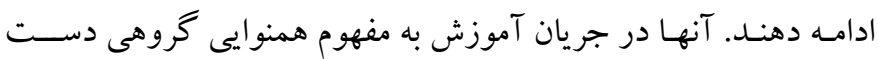

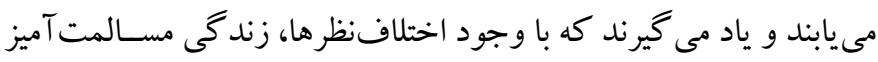

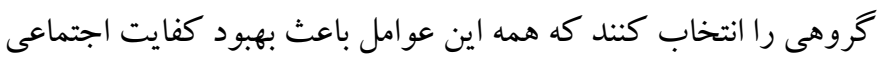

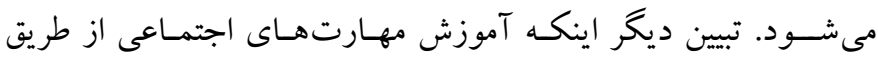
شكل گيرى و ارتقاء روابط و تعامل هاى اجتماعى باعث رشد اجتماعى و ونى

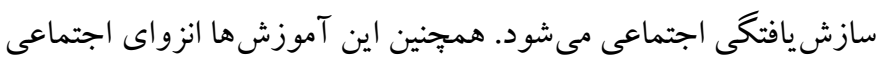

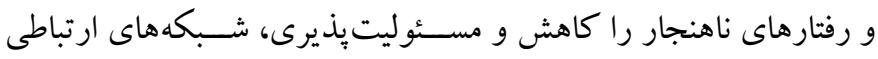
مثبـت و رفتـارهـاى هنجار اجتماعى مانند تعامل هاى مثبت و ســازنده را

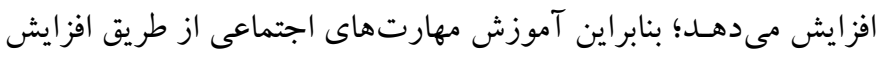

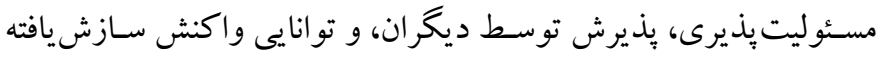
براى مديريت مشكلات اجتماعى، باعث بهبود كفايت اجتماعى مى شود.

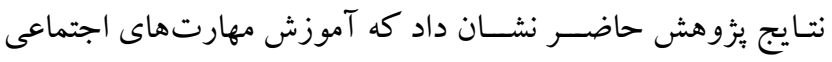

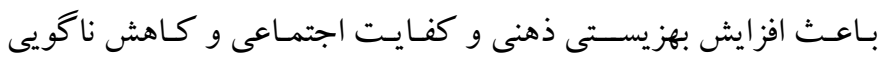

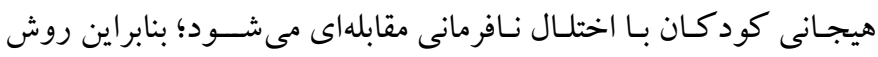
آموزش مهارتهـاى اجتمـاعى در مراكز آموزشـى و درمـانى، قابليت

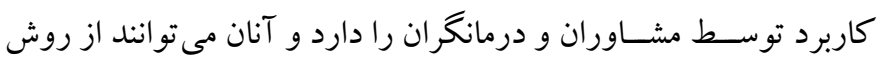

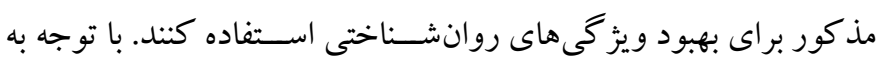
نتايج اين مطالعه به مسـؤل لان و برنامهريزان توصسيه مى شـود اهميت روش

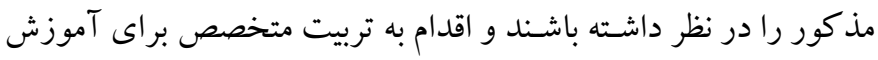

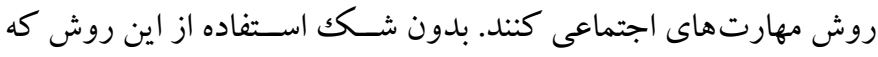

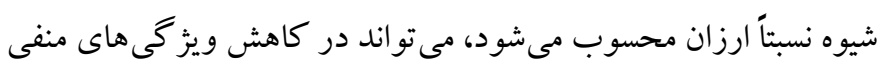
روانشناختى و افزايش ويز كىهاى مثبت روانشناختى كود كان با اختلال

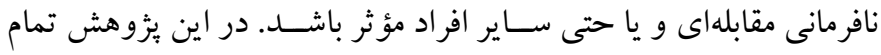

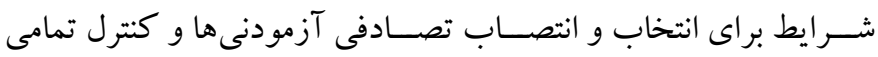

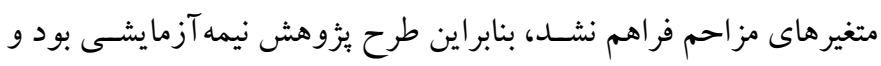

به تنهايى و در صسورت نياز با كمكك ديخران بر شـرايط و موقعيتها فائق آيند و بهزيستى ذهنى خود را ارتقاء بخشند.

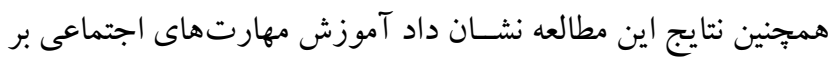

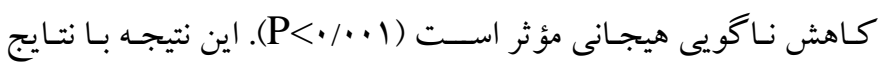

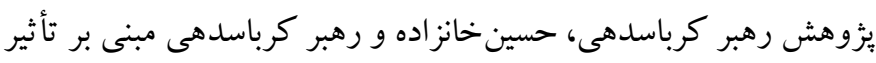

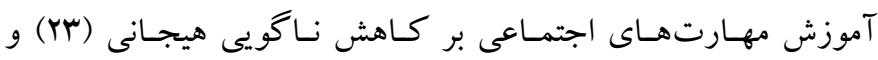

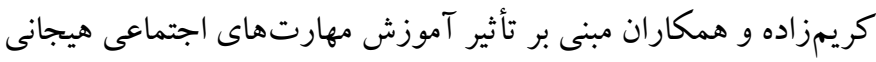

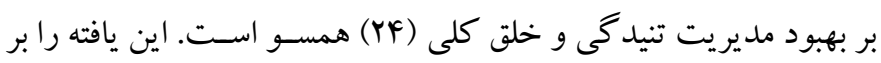

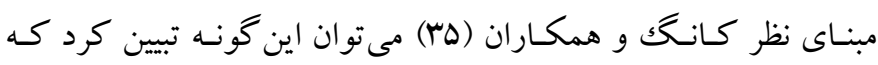

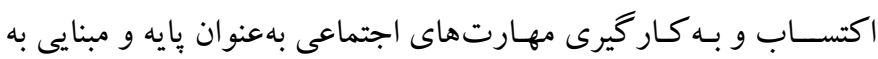

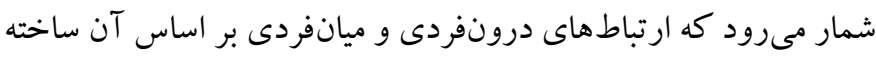

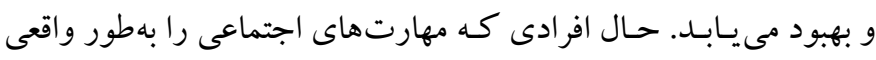

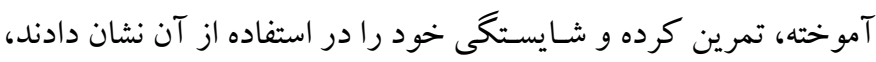

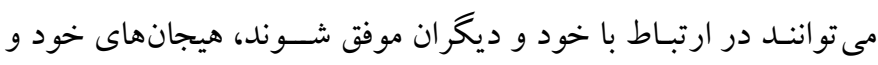

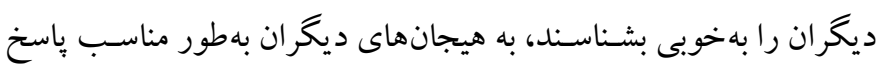

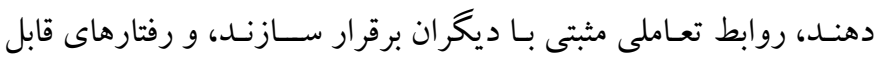

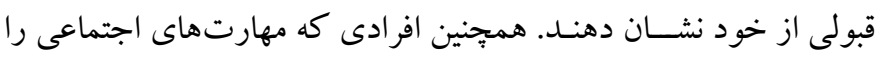

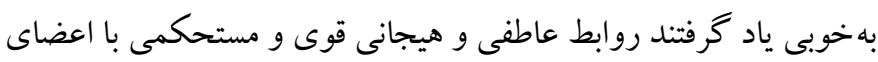

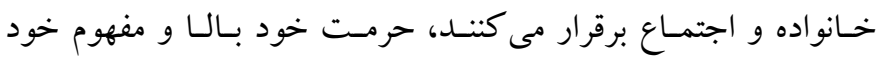

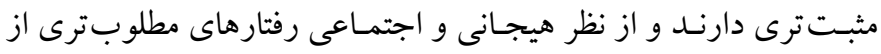

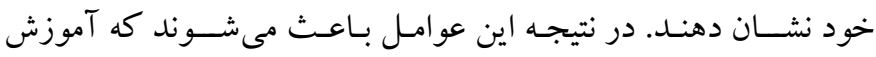
مهارت هاى اجتماعى باعث كاهش ناكويى هيجانى شوند.

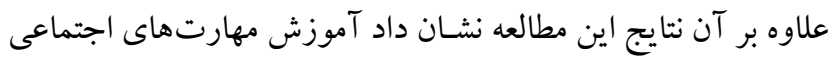

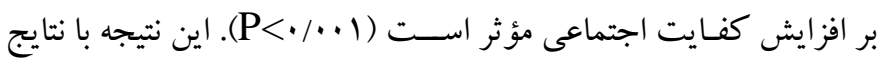

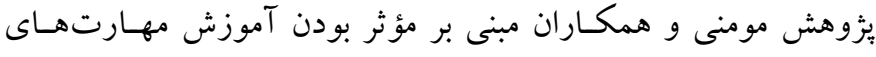

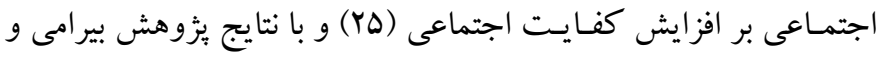

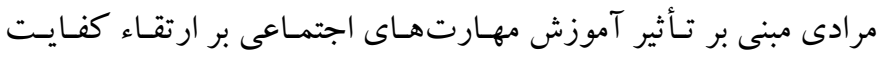

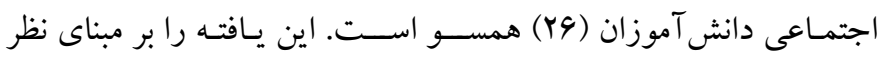

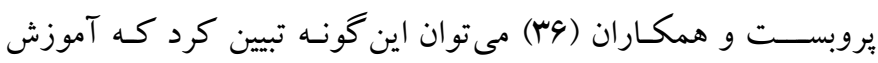

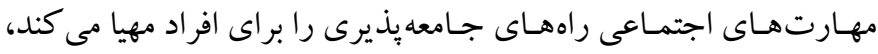
بهورى كه آنها بهعنو ان يكك عضو شايسته و سالم وارد جامعه شوند و از راز

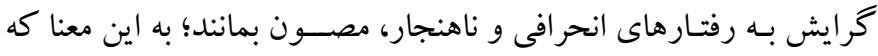


اين كه در اين بزوهش فقط يكك گروه آزمايش وجود داشـت، بيشــنهاد

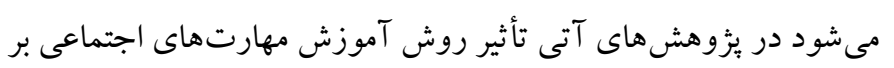

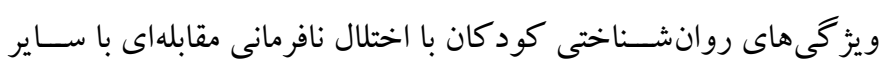

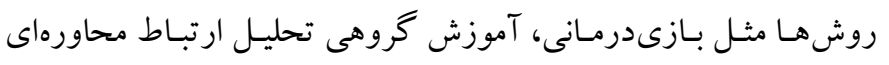

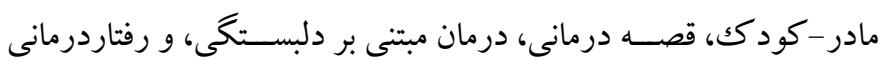

$$
\text { ديالكتيكى مقايسه شود. }
$$

تشـكر و قدردانى: اين مطالعه بهصورت مسـتقل اجرا شــده اسـت و حاصـل

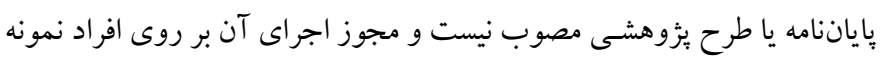

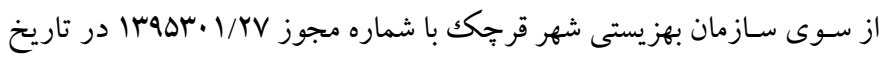

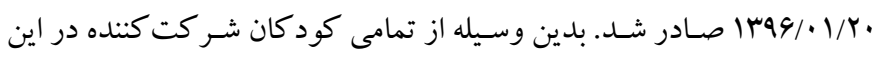

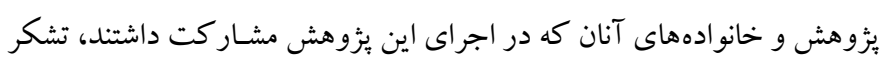

$$
\text { و قدردانى مىشود. }
$$

تضــاد منافع: اين يُزوهش با هزينه شـخصـى انجام شـــه و در آن هيجِ گونه تعارض منافعى براى نويسند كان وجود ندارد.
محسدوديـتهـاى اين گونهه طرحهـا را بـايد در نظر داشــت. با توجه به

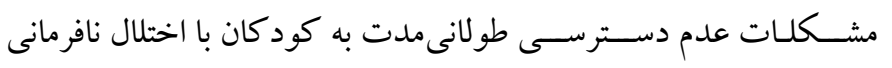

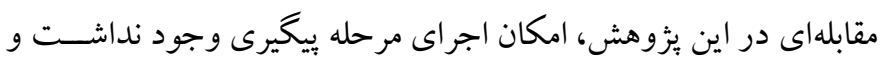

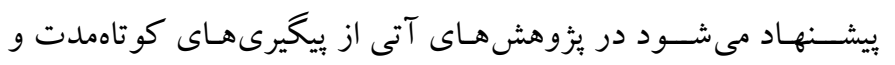

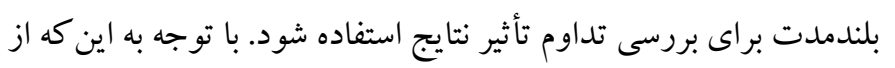

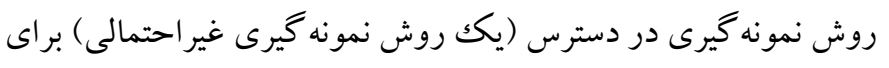

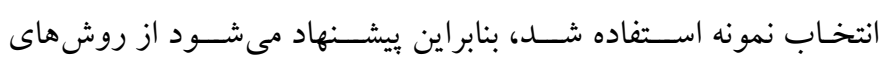

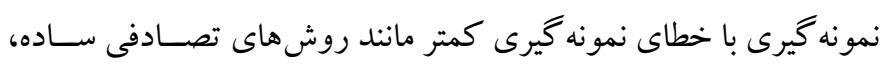

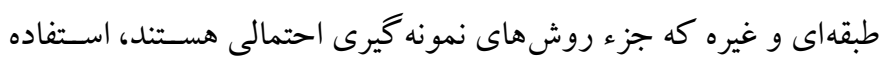

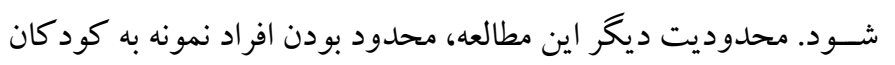

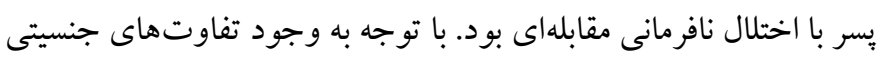

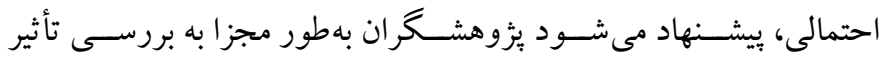

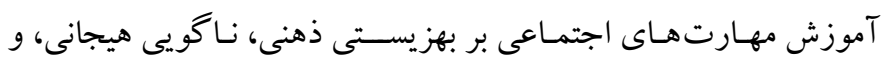

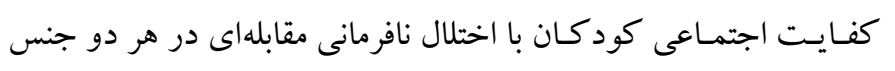

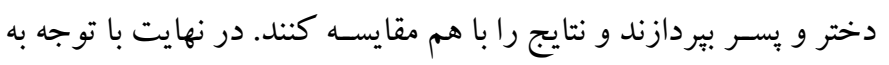




\section{References}

1. Muratori P, Pisano S, Milone A, Masi G. Is emotional dysregulation a risk indicator for auto-aggression behaviors in adolescents with oppositional defiant disorder? J Affect Disord. 2017; 208: 110-112. [Link]

2. HosseinKhanzadeh AA. The effect of child-centered play therapy on the self-efficacy in peer relations among students with oppositional defiant disorder symptoms. Journal of Child Mental Health. 2017; 4(3): 49-59. [Persian]. [Link]

3. Gomez R. Malaysian parent and teacher ratings of the oppositional defiant disorder symptoms: measurement invariance and parent-teacher agreement. Asian J Psychiatr. 2014; 11: 35-38. [Link]

4. Muthoni GF, Michelle K. Oppositional defiant disorder. Journal of Research in Humanities and Social Science. 2014; 2(5): 57-60. [Link]

5. Lamu AN, Olsen JA. The relative importance of health, income and social relations for subjective well-being: an integrative analysis. Soc Sci Med. 2016; 152: 176185. [Link]

6. Von Humboldt S, Leal I, Pimenta F. Sense of coherence, socio demographic, lifestyle, and healthrelated factors in older adults' subjective well-being. Int J Gerontol. 2015; 9(1): 15-19. [Link]

7. Hajdu T, Hajdu G. The association between experiential and material expenditures and subjective well-being: New evidence from Hungarian survey data. J Econ Psychol. 2017; 62: 72-86. [Link]

8. Serafini G, Gonda X, Pompili M, Rihmer Z, Amore M, Engel-Yeger B. The relationship between sensory processing patterns, alexithymia, traumatic childhood experiences, and quality of life among patients with unipolar and bipolar disorders. Child Abuse Negl. 2016; 62: 39-50. [Link]

9. Rehman A, Gumley A, Biello S. Sleep quality and paranoia: the role of alexithymia, negative emotions and perceptual anomalies. Psychiatry Res. 2018; 259: 216-222. [Link]

10. Loas G, Baelde O, Verrier A. Relationship between alexithymia and dependent personality disorder: A dimensional analysis. Psychiatry Res. 2015; 225(3): 484-488. [Link]

11. Goertz-Dorten A, Benesch C, Hautmann C, BerkPawlitzek E, Faber M, Lindenschmidt $\mathrm{T}$, et al. Efficacy of an individualized social competence training for children with oppositional defiant disorders/conduct disorders. Psychother Res. 2017; 27(3): 326-337. [Link]
12. Camras LA, Halberstadt AG. Emotional development through the lens of affective social competence. Curr Opin Psychol. 2017; 17: 113-117. [Link]

13. Gadecka W, Piskorz-Ogorek K, Regin KJ, Kowalski IM. Social competence of mental health nurses. Polish Annals of Medicine. 2015; 22(2): 105-109. [Link]

14. Kovaniemi S, Alakortes J, Carter AS, Yliherva A, Bloigu R, Joskitt LO, et al. How are social-emotional and behavioral competences and problems at age 1 year associated with infant motor development? A general population study. Infant Behav Dev. 2018; 51: 1-14. [Link]

15. Krohling LL, Pereira De Paula KM, Behiau MS. Behavior, social competence, and voice disorders in childhood and adolescence. J Voice. 2016; 30(6): 677683. [Link]

16. Katzmann J, Goertz-Dorten A, Hautmann C, Doepfner M. Social skills training and play group intervention for children with oppositional-defiant disorders/conduct disorder: mediating mechanisms in a head-to-head comparison. Psychother Res. 2019; 29(6): 784-798. [Link]

17. Movallali G, Barati R, Taheri M. Efficacy of social skills training on the reduction of verbal and nonverbal aggression in male students with intellectual disability. Journal of Child Mental Health. 2015; 1(1): 57-66. [Persian]. [Link]

18. Lau EX, Rapee RM, Coplan RJ. Combining child social skills training with a parent early intervention program for inhibited preschool children. J Anxiety Disord. 2017; 51: 32-38. [Link]

19. Coiro MJ, Kotchick BA, Preis J. Youth social skills groups: a training platform for promoting graduate clinician interprofessional competence. J Interprof Educ Pract. 2016; 4: 89-92. [Link]

20. Beidel DC, Alfano CA, Kofler MJ, Rao PA, Scharfstein L, Wong Sarver N. The impact of social skills training for social anxiety disorder: A randomized controlled trial. J Anxiety Disord. 2014; 28(8): 908-918. [Link]

21. Shimada E, Anzai N, Ikebuchi E, Niwa S-I, Nishizono M. Effects of combination pharmacotherapy and social skills training for schizophrenia: A randomized controlled trial. Open J Psychiatr. 2013; 3(3): 273282. [Link]

22. Barghi Irani Z, Bakhti M, Bagiyan Agiyankulemare MJ. The effectiveness of a cognitive processing-based social skills training on the effectiveness of cognitive processing based training of social skills on, emotional, psychological well-being and reducing the 
symptoms of children with conduct disorder. Social Cognition. 2015; 4(1): 157-176. [Persian]. [Link]

23. Rahbar Karbasdehi F, Hosseinkhanzadeh A, Rahbar Karbasdehi E. Effect of social skills training on social self-empowerment and alexithymia in students with specific learning. Exceptional Education. 2017; 2(145): 5-12. [Persian]. [Link]

24. Karimzadeh M, Goodarzi A, Rezaei S. The effect of social emotional skills training to enhance general health\& Emotional Intelligence in the primary teachers. Procedia Soc Behav Sci. 2012; 46: 57-64. [Link]

25. Momeni S, Barak M, Kazemi R, Abolghasemi A, Babaei M, Ezati F. Study of the effectiveness of social skills training on social and emotional competence among students with mathematics learning disorder. Creat Educ. 2012; 3(8): 1307-1310. [Link]

26. Beyrami M, Moradi A. The effect of teaching social skills on competence of students (Felner Model). Journal of Modern Psychological Researches. 2007; 1(4): 47-67. [Persian]. [Link]

27. Hommersen P, Murray C, Ohan J, Johnston C. Oppositional defiant disorder rating scale: preliminary evidence of reliability and validity. J Emot Behav Disord. 2006; 14(2): 118-125. [Link]

28. Behroozy N, Farzadi F, Faramarzi H. Investigating the causal relationship of parents' physical and emotional violence with anger management and aggressive behavior of children with oppositional defiant disorder mediated by parent-child relationship and empathy. Journal of Child Mental Health. 2016; 3(3): 43-58. [Persian]. [Link]

29. Nasiri Kanari F, Alivandi Vafa M. The prediction of pregnancy anxiety on the basis of subjective wellbeing and happiness of pregnant women in Tabriz. Depiction of Health. 2017; 8(1): 34-43. [Persian]. [Link]
30. Aydin A. A comparison of the alexithymia, selfcompassion and humour characteristics of the parents with mentally disabled and autistic children. Procedia Soc Behav Sci. 2015; 174: 720-729. [Link]

31. Besharat MA. Reliability and factorial validity of Farsi version of the Toronto alexithymia scale with a sample of Iranian students. Psychol Rep. 2007; 101(1): 209-220. [Link]

32. Abolghasemi A, Rezaee H, Narimani M, Zahed Babolan A. A comparison of social competence and its components in students with learning disability and students with low, average and high academic achievement. Journal of Learning Disabilities. 2012; 1(1): 6-23. [Persian]. [Link]

33. Sourani Yancheshmeh R. The effect of social skills training on subjective well-being, health adjustment and family social function of students. Journal of Social Psychology. 2018; 2(45): 1-10. [Persian]. [Link]

34. Cook CR, Gresham FM, Kern L, Barreras RB, Thornton S, Crews SD. Social skills training for secondary students with emotional and/or behavioral disorders: a review and analysis of the meta-analytic literature. J Emot Behav Disord. 2008; 16(3): 131144. [Link]

35. Kang R, Wu Y, Li Z, Jiang J, Gao Q, Yu Y, et al. Effect of community-based social skills training and tai-chi exercise on outcomes in patients with chronic schizophrenia: a randomized, one-year study. Psychopathology. 2016; 49(5): 345-355. [Link]

36. Probst T, Geib C, Güroff E, Mühlberger A. Training the social skill "being able to demand" vs. training the social skill "being able to say no". A randomized controlled trial with healthy individuals. J Behav Ther Exp Psychiatry. 2017; 57: 1-5. [Link] 